\title{
Drug treatment of primary hyperparathyroidism: use of clodronate disodium
}

\author{
D L DOUGLAS, J A KANIS, A D PATERSON, D J BEARD, E C CAMERON, M E WATSON, \\ $S$ WOODHEAD, J WILLIAMS, R G G RUSSELL
}

\begin{abstract}
Clodronate disodium (dichloromethylene diphosphonate), a specific inhibitor of bone resorption, was given by mouth (1.0-3.2 $\mathrm{g}$ daily) to nine patients with primary hyperparathyroidism for two to 32 weeks so that its clinical and metabolic effects could be evaluated. Bone resorption decreased in all patients as judged by a fall in the fasting urinary calcium to creatinine and hydroxyproline to creatinine ratios. Serum calcium concentration was increased in all patients before treatment and fell in response to treatment to values near the upper end of the normal range. Hypercalcaemia and hypercalciuria recurred when treatment was stopped. In three patients treated for longer than 19 weeks clodronate failed to sustain the reduction in serum calcium concentration but the concentration remained below pretreatment values.
\end{abstract}

These results suggest that clodronate may be of use in the medical management of primary hyperpara-

Department of Human Metabolism and Clinical Biochemistry,
University of Sheffield Medical School, Sheffield S10 2RX
D L DOUGLAS, FRCSED, Wellcome surgical research fellow (now ortho-
paedic registrar, Nuffield Orthopaedic Centre, Oxford)
J A KANIS, BSC, MRCP, reader
A D PATERSON, MRCP, clinical research fellow
D J BEARD, FRCS, MRC clinical research fellow
E C CAMERON, MD, physician (on leave from department of medicine,
University of British Columbia, Vancouver, Canada)
R G G RUSSELL, DM, FRCP, professor
Department of Urology, Royal Hallamshire Hospital, Sheffield S10 2RX

M E WATSON, PHD, FRCS, senior registrar

J WILLIAMS, FRCS, consultant

Department of Medical Biochemistry, Welsh National School of Medicine, Cardiff CF4 4XN

$S$ WOODHEAD, PHD, senior lecturer thyroidism, particularly in patients in whom suppression of bone disease is desirable before surgery or in whom surgery is contraindicated.

\section{Introduction}

The usual and preferred treatment of symptomatic primary hyperparathyroidism is by surgical removal of the parathyroid adenoma or hyperplastic glands. In mild, asymptomatic cases, however, particularly in the elderly or unfit, the role of surgery is controversial. ${ }^{2}$ In such patients it is often uncertain whether symptoms, such as dyspepsia, or signs, such as hypertension, are related to the increased plasma calcium concentration. In some patients it may be advantageous to reduce the serum calcium concentration by medical management so that the indications for surgery may be assessed. In other patients with appreciable hypercalcaemia, who are unfit for surgery or in whom the diagnosis is not immediately clear, reducing the serum calcium concentration and improving the patient's general condition confer obvious advantages.

There are several approaches to the medical management of hypercalcaemia, which may include administration of oral phosphate and, in acute crises, repletion of extracellular fluid volume. $^{34}$ Specific inhibitors of bone resorption, such as calcitonin and mithramycin, are a logical treatment of hypercalcaemia if bone resorption is increased but have not been extensively studied in the management of hyperparathyroidism. Sherwood et $a l^{5}$ reported that the $\mathrm{H}_{2}$-receptor antagonist cimetidine reduced plasma calcium concentrations and suppressed immunoreactive parathyroid hormone in 12 patients with primary hyperparathyroidism. Others found that cimetidine had little effect in reducing plasma calcium concentration. ${ }^{6}$ ? The diphosphonates clodronate disodium (dichloromethylene diphosphonate; $\mathrm{Cl}_{2} \mathrm{MDP}$ ) and 3-aminopropylidine-1,1-diphosphonate are powerful inhibitors of bone resorption and have been used successfully in reducing increased bone resorption in Paget's disease of bone, ${ }^{8-11}$ in controlling hypercalcaemia associated with myeloma or metastatic bone disease, ${ }^{1012-14}$ and in primary hyperparathyroidism..$^{15}$ Our own preliminary 
findings using clodronate in four patients with primary hyperparathyroidism ${ }^{10}$ encouraged us to extend these observations to a larger number of patients studied for longer periods.

\section{Patients and methods}

The effects of treatment with clodronate were studied in nine patients aged 61-72 years with primary hyperparathyroidism (table I). Complications of hyperparathyroidism in these patients included renal calculi (three patients), skeletal pain (three), and constipation and nocturia (one).

No patient was receiving thiazide diuretics, and only one (case 7) was judged to be dehydrated. This patient was treated for three days with infusions of sodium chloride before study. All patients had normal renal function (plasma creatinine concentration less than $120 \mu \mathrm{mol} / 1(1.4 \mathrm{mg} / 100 \mathrm{ml}))$ and biochemical evidence of hyperparathyroidism as judged by sustained hypercalcaemia, a low serum phosphate concentration, and decreased tubular reabsorption of phosphate. Immunoreactive parathyroid hormone was detectable in serum in all patients, the values being either in the normal range or raised. Five patients underwent successful parathyroidectomy after completion of the study. One patient (case 5) was admitted to the study because of recurrence of hypercalcaemia after previous surgery for parathyroid hyperplasia.

Urine and blood were collected at intervals of one to seven days for biochemical determinations before and during treatment. Blood was taken after an overnight fast and serum separated for determination of calcium, phosphate, and creatinine concentrations, alkaline phosphatase activity, albumin concentration, and liver transaminase activities (Technicon SMAC). Serum was also stored at $-20^{\circ} \mathrm{C}$ for subsequent analysis of immunoreactive parathyroid hormone Haematological tests (haemoglobin concentration, white cell count, and platelet count) were performed with a Technicon Haemalog 8 .

After an overnight fast patients emptied their bladders and then collected urine for the next two hours ("fasting urine"). The urine produced over the subsequent 22 hours was collected separately. Urine measurements included calcium, phosphate, and creatinine concentrations (Technicon SMAC). Urinary excretion of peptidebound hydroxyproline was measured by a modification of Stegemann's method. ${ }^{16}$ Renal tubular reabsorption of phosphate was calculated as the ratio of maximal tubular reabsorption of phosphate to glomerular filtration rate. ${ }^{12}$

Urinary excretion of hydroxyproline was expressed as a ratio to the creatinine concentration in urine. Calcium excretion was expressed as $\mathrm{mmol}$ calcium/l glomerular filtrate. ${ }^{18}$ Serum immunoreactive parathyroid hormone was assayed by an immunoradiometric method ${ }^{19}$ with a guinea pig antiserum raised against bovine parathyroid hormone (code BW 211/42, provided by the Medical Research Council). Samples were assayed against a reference preparation of human parathyroid hormone $(75 / 549)$ provided by the National Institute for Biological Standards and Control, and the assay procedure was fully automated with the Kemtek 3000 (Kemble Instrument Co, Burgess Hill, Sussex).

Clodronate $(1 \cdot 0-3 \cdot 2 \mathrm{~g}$ daily) was given as a single dose before breakfast. If gastrointestinal side effects such as diarrhoea were noted it was administered in two or three divided doses throughout the day.

The significance of the difference between treatment periods was calculated with Student's $t$ test for paired observations.

\section{Results}

\section{CLINICAL RESPONSES}

In two of the three patients with skeletal pain, this decreased during treatment. None of the three patients with a history of renal calculi had further loin pain, and no stones were passed during treatment, although the period of observation (two to 32 weeks) was insufficient to judge whether stone frequency decreased. A bladder stone was diagnosed during treatment in a further patient (case 9 ; table I) 0 and subsequently removed by litholopaxy. One patient who was severely hypercalcaemic (serum calcium concentration $4.1 \mathrm{mmol} / 1$ 孚 $(16.4 \mathrm{mg} / 100 \mathrm{ml})$ ) remained hypercalcaemic after volume repletion and clodronate for two weeks (serum calcium concentration 3.55 $\mathrm{mmol} / 1(14 \cdot 2 \mathrm{mg} / 100 \mathrm{ml}))$, and he underwent successful parathyroidectomy for a single adenoma.

The drug was well tolerated with no detectable changes in hepatic, $\triangle$ renal, or haematological function. The only side effect noted was कै mild gastrointestinal disturbance in one patient, which was controlled by dividing the daily dose of clodronate.

\section{BIOCHEMICAL RESPONSES}

Serum calcium concentration fell to normal or near normal in the patients treated with clodronate for five weeks or longer (table II, $\stackrel{\infty}{\infty}$ fig 1). The fall in concentration ranged from 0.06 to $0.65 \mathrm{mmol} / 1$

TABLE II-Mean $\pm S E M$ biochemical measurements before and during treatment of primary hyperparathyroidism with clodronate

\begin{tabular}{|c|c|c|c|c|}
\hline & $\begin{array}{c}\text { No } \\
\text { of } \\
\text { patients }\end{array}$ & $\begin{array}{c}\text { Before } \\
\text { treatment }\end{array}$ & $\begin{array}{l}\text { After six } \\
\text { weeks' } \\
\text { treatment }\end{array}$ & $\begin{array}{c}\text { Significance } \\
\text { of } \\
\text { difference }\end{array}$ \\
\hline $\begin{array}{l}\text { Serum calcium (corrected for } \\
\text { serum albumin) }(\mathrm{mmol} / \mathrm{l})\end{array}$ & 8 & $2.88+0.09$ & $2.63 \pm 0.05$ & $\mathrm{p}<0.01$ \\
\hline $\begin{array}{l}\text { Fasting calcium excretion } \\
\text { (mmol/l glomerular filtrate) } \\
\text { Fasting hydroxyproline }\end{array}$ & 8 & $0.058 \pm 0.006$ & $0.018+0.002$ & $p<0.001$ \\
\hline $\begin{array}{l}\text { excretion }(\mathrm{mmol} / \mathrm{mol} \\
\text { creatinine }) \\
\text { Serum phosphate }(\mathrm{mmol} / \mathrm{l}) \\
\text { Serum creatinine }(\mu \mathrm{mol} / \mathrm{l}) \\
\text { Renal tubular reabsorption of }\end{array}$ & $\begin{array}{l}8 \\
8 \\
8\end{array}$ & $\begin{array}{c}42 \pm 8 \\
0 \cdot 79 \pm 0.03 \\
85 \cdot 5 \pm 4 \cdot 6\end{array}$ & $\begin{array}{c}17+2 \\
0 \cdot 73 \pm 0 \cdot 03 \\
81 \cdot 4 \pm 3 \cdot 6\end{array}$ & $\begin{array}{c}\mathrm{p}<0.02 \\
\text { NS } \\
\text { NS }\end{array}$ \\
\hline $\begin{array}{l}\text { phosphate (mmol/1) } \\
\text { Immunoreactive parathyroid }\end{array}$ & 7 & $0.65 \pm 0.06$ & $0.60 \pm 0.06$ & NS \\
\hline $\begin{array}{l}\text { Immunoreactive parathyroid } \\
\text { hormone }(\mu \mathrm{g} / \mathrm{l}) \\
\text { Serum alkaline phosphatase }\end{array}$ & 8 & $1 \cdot 28 \pm 0.48$ & $1 \cdot 13 \pm 0 \cdot 42$ & NS \\
\hline $\begin{array}{l}\text { Serum alkaline phospnatase } \\
\text { (IU / }) \\
\text { Urine calcium (mmol/24 h) }\end{array}$ & $\begin{array}{l}8 \\
4\end{array}$ & $\begin{aligned} 99 & \pm 11 \\
8 \cdot 02 & \pm 1 \cdot 7\end{aligned}$ & $\begin{array}{l}100 \pm 11 \\
6 \cdot 02 \pm 0 \cdot 8\end{array}$ & $\begin{array}{l}\text { NS } \\
\text { NS }\end{array}$ \\
\hline
\end{tabular}

Conversion: SI to traditional units-Serum calcium: $1 \mathrm{mmol} / 1 \approx 4 \mathrm{mg} / 100 \mathrm{ml}$. Calcium excretion: $1 \mathrm{mmol} / 1$ glomerular filtrate $\approx 4 \mathrm{mg} / 100 \mathrm{ml}$. Hydroxyprolin excretion: $1 \mathrm{mmol} / \mathrm{mol}$ creatinine $\approx 1 \cdot 16 \mathrm{mg} / \mathrm{g}$. Serum phosphate: $1 \mathrm{mmol} / 1 \approx 3 \cdot 1 \mathrm{mg} /$ $100 \mathrm{ml}$. Serum creatinine: $1 \mu \mathrm{mol} / 1 \approx 11.3 \mu \mathrm{g} / 100 \mathrm{ml}$. Renal tubular reabsorption of phosphate: $1 \mathrm{mmol} / 1 \approx 3.1 \mathrm{mg} / 100 \mathrm{ml}$. Urine calcium: $1 \mathrm{mmol} / 24 \mathrm{~h} \approx 40 \mathrm{mg} / 24 \mathrm{~h}$.

$(0.2$ to $2.6 \mathrm{mg} / 100 \mathrm{ml})$. The maximum reduction was reached at two months after the start of treatment. The fall was proportional to the initial concentration $(r=0.82 ; p<0.02)$ but did not correlate with the initial serum alkaline phosphatase activity. In all patients bone resorption was considerably reduced as indicated by a fall in fasting urinary excretion of calcium and hydroxyproline (table II). One patient (case 8) remained hypercalcaemic after two weeks of 


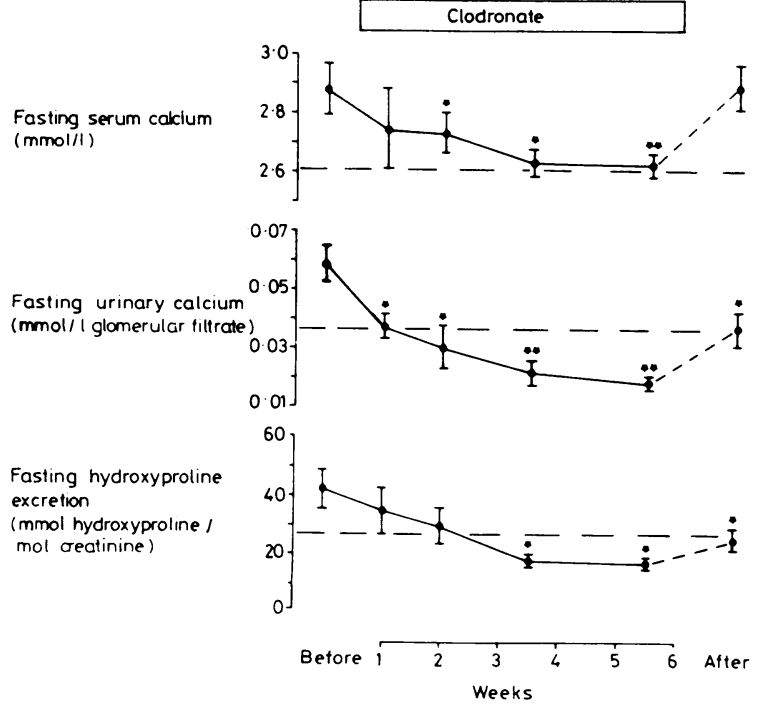

Fig 1-Mean : SEM effects of clodronate in eight patients with primary hyperparathyroidism. Broken line indicates upper limit of normal range.

${ }^{*} \mathrm{p}<0.05 ;{ }^{* *} \mathrm{p}<0 \cdot 01$

Conversion: SI to traditional units-Serum calcium: $1 \mathrm{mmol} / 1 \approx 4$ $\mathrm{mg} / 100 \mathrm{ml}$. Urine calcium: $1 \mathrm{mmol} / 1$ glomerular filtrate $\approx 4 \mathrm{mg} /$ $100 \mathrm{ml}$. Hydroxyproline excretion: $1 \mathrm{mmol} / \mathrm{mol}$ creatinine $\approx$ $1 \cdot 16 \mathrm{mg} / \mathrm{g}$.

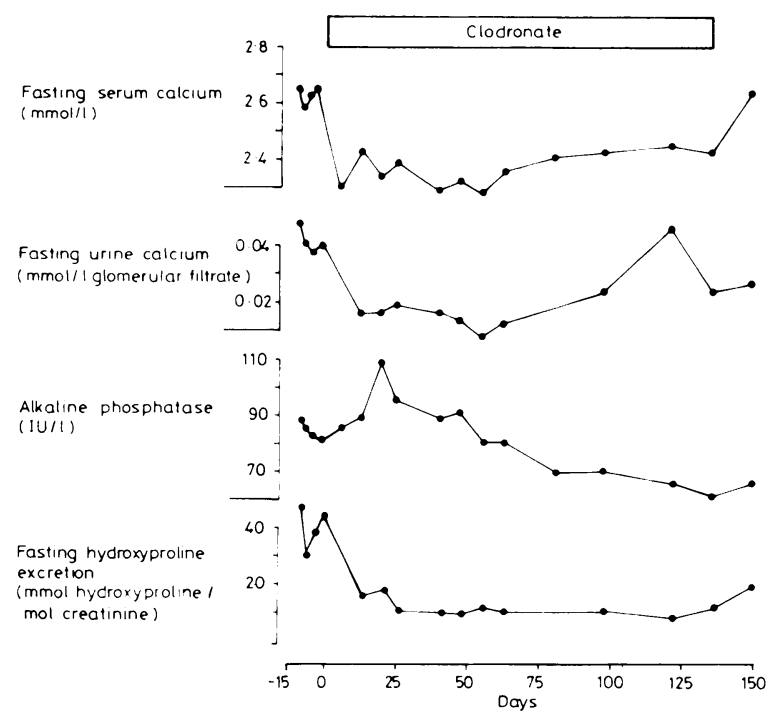

FIG 2-Effects of long-term treatment with clodronate in patient (case 6) with primary hyperparathyroidism.

Conversion: SI to traditional units-Serum calcium: $1 \mathrm{mmol} / 1 \approx 4$ $\mathrm{mg} / 100 \mathrm{ml}$. Urine calcium: $1 \mathrm{mmol} / \mathrm{l}$ glomerular filtrate $\approx 4 \mathrm{mg} /$ $100 \mathrm{ml}$. Hydroxyproline excretion: $1 \mathrm{mmol} / \mathrm{mol}$ creatinine $\approx$ $1 \cdot 16 \mathrm{mg} / \mathrm{g}$.

treatment with clodronate (serum calcium concentration fell from 4.1 to $3.55 \mathrm{mmol} / 1(16.4$ to $14.2 \mathrm{mg} / 100 \mathrm{ml}))$, when a parathyroid adenoma was removed.

The 24-hour urinary excretion of calcium was measured serially in four patients and fell from $8.02+$ SEM 1.77 to $6.02+0.8 \mathrm{mmol} / 24 \mathrm{~h}$ (320 70 to $240 ! 30 \mathrm{mg} / 24 \mathrm{~h}$ ) during treatment. In contrast to the rapid and consistent fall in excretion of hydroxyproline the response of serum alkaline phosphatase activity varied. In three patients a fall in alkaline phosphatase activity occurred which was preceded by a "flare" (fig 2). No consistent changes were observed in serum phosphate concentration or renal tubular reabsorption of phosphate.

After treatment with clodronate was stopped hypercalcaemia recurred and urinary excretion of both calcium and hydroxyproline rose towards pretreatment values (fig 1). One patient (case 5) was given a second course of clodronate, which reversed these changes. In the three patients who were treated for 19 weeks or more serum and urinary calcium began to return towards pretreatment values.

\section{Discussion}

All nine patients studied showed evidence that clodronate suppressed bone resorption, as indicated by a fall in the urinary excretion of calcium and hydroxyproline into the normal range. Serum calcium concentration, however, fell generally only to the upper part of the normal range. The failure to suppress serum calcium concentration to normal despite a fall in fasting calcium excretion suggests that renal tubular resorption of calcium remained high in these patients, ${ }^{3}$ reflecting the continued secretion of parathyroid hormone despite treatment.

Net bone resorption was increased in all patients before treatment as judged by urinary excretion of calcium and hydroxyproline. The mechanism responsible for the fall in serum and urinary calcium probably includes drug-induced inhibition of bone resorption without inhibition of bone formation. This suggests that there is a temporary "uncoupling" between the rates of bone resorption and bone formation, which are usually closely linked, under both normal and abnormal conditions. ${ }^{20} \mathrm{~W}$ ith prolonged treatment, however, serum calcium concentration and urinary calcium excretion increased, suggesting that a recoupling of bone resorption and formation had taken place. The implications that the hypocalcaemic effect of clodronate relies on its ability to dissociate transiently mineral accretion from resorption suggests that clodronate might be of limited value in the long-term medical management of primary hyperparathyroidism, but more extensive work is required on a larger number of patients to determine whether the drug is of only short-term benefit.

These inhibitors of bone resorption may be useful not only in treating patients who are unsuitable for surgery but in preparing patients with extensive bone disease for surgery. If bone disease is suppressed preoperatively the "hungry bone" syndrome, which produces postoperative hypocalcaemia, ${ }^{21}$ may be avoided, leading to a safer and less troublesome postoperative recovery.

In the only other reported study of clodronate in primary hyperparathyroidis $\mathrm{m}^{15}$ the patients had milder disease than ours and were treated for shorter periods. None the less, a small but significant reduction in plasma calcium concentration occurred. The diphosphonate sodium etidronate, used to treat heterotopic ossification and Paget's disease, ${ }^{22}$ has been studied to only a limited extent. In the study by Kaplan et $a l^{23}$ sodium etidronate reduced urinary excretion of calcium and hydroxyproline but produced a significant reduction in serum calcium concentration in only two of the six patients studied. Our own preliminary observations with sodium etidronate suggest that it is less effective than clodronate in reducing the hypercalcaemia of hyperparathyroidism.

Our present observations therefore suggest that clodronate is a promising drug for at least the short-term medical management of hypercalcaemia in primary hyperparathyroidism.

We are grateful to the Wellcome Trust, the Medical Research Council, the Medical Research and Rehabilitation Trust, and the special trustees of the United Sheffield Hospitals for supporting this work. Clodronate disodium was kindly supplied by Procter and Gamble Company and the Istituto Gentili.

\section{References}

${ }^{1}$ Coe FL, Flavus MJ. Does mild, asymptomatic hyperparathyroidism require surgery ? $N$ Engl f Med 1980;302:224-5.

2 Anonymous. Mild asymptomatic hyperparathyroidism. (Editorial.) $\mathrm{Br}$ Med f 1980;281:174-5.

"Kanis JA, Cundy T, Heynen G, Russell RGG. The pathophysiology of hypercalcaemia. Metabolic Bone Disease and Related Research 1980;2: 151-60. 
${ }^{4}$ Hosking DJ. Treatment of severe hypercalcaemia with calcitonin. Metabolic Bone Disease and Related Research 1980;2:207-12.

${ }^{5}$ Sherwood JK, Ackroyd FW, Garcia M. Effect of cimetidine on circulating parathyroid hormone in primary hyperparathyroidism. Lancet $1980 ; \mathrm{i}$ : 616-9.

${ }^{6}$ Palmer FJ, Sawyers TM, Wierzbinski SJ. Cimetidine and hyperparathyroidism. N Engl f Med 1980;302:692.

7 Heath H. Cimetidine in hyperparathyroidism. Lancet 1980;i:980.

${ }^{8}$ Frijlink WB, Bijvoet OLM, Velde J, Heynen G. Treatment of Paget's disease with (3-amino-1-hydroxypropylidene)-1,1-bisphosphonate (APD). Lancet 1979;i:799-803.

${ }^{9}$ Meunier PJ, Chapuy MC, Alexandre C, et al. Effects of disodium dichloromethylene diphosphonate on Paget's disease of bone. Lancet 1979 ;ii : $489-92$.

${ }^{10}$ Douglas DL, Duckworth T, Russell RGGR, et al. Effect of dichloromethylene diphosphonate in Paget's disease of bone and in hypercalcaemia due to primary hyperparathyroidism or malignant disease. Lancet 1980; i:1043-7.

11 Douglas DL, Duckworth T, Kanis JA, et al. Biochemical and clinical responses to dichloromethylene diphosphonate $\left(\mathrm{Cl}_{2} \mathrm{MDP}\right)$ in Paget's disease of bone. Arthritis Rheum 1980;23:1185-92.

12 van Breukelen FJM, Bijvoet OLM, van Oosterom AT. Inhibition of osteolytic bone lesions by 3-amino-1-hydroxypropylidene-1,1 bisphosphonate (APD). Lancet 1979; i:803-5.

${ }^{13}$ Siris ES, Sherman WH, Baquiran DC, Schlatterer JP, Osserman EF, Canfield RE. Effects of dichloromethylene diphosphonate on skeletal mobilisation of calcium in multiple myeloma. $N$ Engl f Med 1980; 302:310-5.
${ }^{14}$ Chapuy MC, Meunier PJ, Alexandre CM. Effects of disodium dichloromethylene diphosponate on hypercalcaemia produced by bone metastases. 7 Clin Invest 1980;65:1243-7.

15 Shane E, Baquiran DC, Bilezikian JP. Effects of dichloromethylene diphosphonate on serum and urinary calcium in primary hyperparathyroidism. Ann Intern Med $1981 ; 95: 23-7$.

${ }^{16}$ Stegemann H. Mikrobestimmung von Hydroxyprolin mit Chloramin-T und p-Dimethylamino-benzaldehyd. Hoppe-Seyler's Zeitschrift für physiologishe Chemie 1958;311:41-5.

${ }^{17}$ Bijvoet OLM, Morgan DB, Fourman P. The assessment of phosphate reabsorption. Clin Chim Acta 1969;26:15-24.

${ }^{18}$ Nordin BEC. Diagnostic procedures. In: Nordin BEC, ed. Calcium, phosphate, and magnesium metabolism. Edinburgh, London, and New York: Churchill Livingstone, 1976:469-524.

${ }^{19}$ Addison GM, Hales CN, Woodhead JS, O'Riordan JLM. Immunoradiometric assay of parathyroid hormone. $\mathcal{F}$ Endocrinol 1971;49:521-30.

20 Harris WH, Heaney RP. Skeletal renewal and metabolic bone disease. $N$ Engl f Med 1969;280:193-202, 253-9, 303-11.

${ }^{21}$ Neer RM, Potts JT. Medical management of hypercalcaemia and hyperparathyroidism. In: de Groot LJ, ed. Endocrinology. Vol II. New York and London: Grune and Stratton, 1979:725-34.

${ }^{22}$ Kanis JA, Russell RGG, eds. Diphosponates and Paget's disease of bone. Metabolic Bone Disease and Related Research $1981 ; 3:$ Nos 4 and 5.

${ }^{23}$ Kaplan RA, Geho WB, Poindexter C, Haussler M, Dietz GW, Pak CYC. Metabolic effects of diphosphonate in primary hyperparathyroidism. f Clin Pharmacol 1977;17:410-9.

(Accepted 11 November 1982)

\title{
Maturity onset diabetes of the young is not linked to the insulin gene
}

\author{
J I BELL, J S WAINSCOAT, J M OLD, C CHLOUVERAKIS, H KEEN, R C TURNER, \\ D J WEATHERALL
}

\begin{abstract}
Maturity onset diabetes of the young is inherited as an autosomal dominant condition. Two families with the disease were studied to determine whether the inheritance of this type of diabetes was linked to the insulin gene. A cloned insulin gene probe was hybridised to DNA from the family members and the insulin gene on each chromosome identified by a different fragment length polymorphism.

The results showed no linkage between the insulin gene and the inheritance of maturity onset diabetes of the young.
\end{abstract}

\footnotetext{
Nuffield Department of Clinical Medicine, John Radcliffe Hospital, Headington, Oxford

J I BELL, MA, MRCP, research fellow

J S WAINSCOAT, MRCP, MRCPATH, MRC training fellow

J M OLD, PHD, senior biochemist

R C TURNER, MD, FRCP, clinical reader

D J WEATHERALL, FRCP, Nuffield professor of clinical medicine

Unit for Metabolic Medicine, Guy's Hospital, London SE1 9RT

C CHLOUVERAKIS, MD, honorary consultant

H KEEN, MD, MRCP, professor of metabolic medicine
}

\section{Introduction}

The genetic basis of non-insulin dependent diabetes mellitus remains poorly understood. Although a high level of concordance exists in twin studies, ${ }^{1}$ a clear pattern of inheritance has not emerged from family or linkage studies. One reason for this is the pronounced heterogeneity of the disease. ${ }^{2}$ A subgroup of non-insulin dependent diabetes in which genetic analysis might prove more fruitful was described by Tattersall and Fajans. ${ }^{34}$ This subgroup, referred to as "maturity onset diabetes in the young," is manifested by non-ketotic diabetes which develops in early adult life and persists with little progression and few complications, and it provides several advantages as a subgroup for genetic analysis. Firstly, it is inherited in a pattern consistent with an autosomal dominant trait; $53 \%$ of siblings are affected and $85 \%$ of patients have a parent with diabetes. This pattern of inheritance allows linkage studies to be performed within families using genetic markers. Secondly, because the disease is usually expressed at a young age it is often possible to analyse several generations of one family and avoid inaccuracies that result from failing to identify subjects who would later develop diabetes.

Results of linkage analysis of affected families with a wide range of genetic markers, including the HLA loci, have all been negative. ${ }^{5}$ The cloning and sequencing of the insulin gene has, however, led to the discovery of a new marker, a highly variable length polymorphism adjacent to the $5^{\prime}$ end of the insulin gene, which may be identified by restriction endonuclease gene mapping. ${ }^{6}$ Patients with maturity onset diabetes of the young often show both low insulin concentrations and a poor response of insulin to glucose challenge ${ }^{78}$; hence it is important to determine whether a locus in the region of the insulin gene is 